\title{
Soeharto dan Gerakan 30 September (G30s) dalam Narasi Memori Media Berita Daring Indonesia
}

\author{
Muhammad Aswan Zanynu \\ Departemen Ilmu Komunikasi, Fakultas Ilmu Sosial dan Ilmu Politik, Universitas Halu Oleo \\ Kampus Hijau Bumi Tridharma, Kendari, Sulawesi Tenggara 93232 \\ aswan.zanynu@gmail.com
}

Diterima: Mei, 2019 Direview: Mei 2019 Diterbitkan: Juni, 2019

\begin{abstract}
Abstrak. Gerakan 30 September (G30S) merupakan salah satu momen penting dalam sejarah modern Indonesia. Soeharto sebagai tokoh yang memainkan sejumlah peran strategis di tahun 1965 penting untuk menjadi objek kajian mengingat peristiwa itu yang membawanya selama lebih dari tiga puluh tahun berada di tampuk kekuasaan Indonesia, menggantikan Presiden Sukarno. Selama kurun waktu itu juga, G30S telah menjadi alat propaganda negara. Setelah dua dekade Soeharto tidak berkuasa lagi dan peristiwa ini telah memasuki usia setengah abad, di tahun 2015 sejumlah media berita daring (online) Indonesia mengisahkan kembali peristiwa tersebut. Studi ini berangkat dari premis bahwa besarnya kapasitas ruang di internet dan dukungan pranala (hypertext) pada web, termasuk banyaknya referensi terkait Peristiwa G30S dan pasca-G30S, memungkinkan situs berita menyajikan memori yang lebih lengkap dan beragam. Penelitian ini mendiskusikan media berita daring Indonesia menarasikan pewarisan memori atas peran Soeharto dan G30S setelah setengah abad berlalu. Dengan menggunakan konsep memori media dari Motti Neiger dkk serta teori Paradigma Naratif Fisher, studi ini menggunakan metode framing dari Pan dan Kosicki untuk menganalisis 27 artikel yang tersebar di enam situs berita Indonesia. Ditemukan bahwa Soeharto ditampilkan dalam dua narasi utama. Pertama, Soeharto sebagai tokoh militer 'penyelamat' yang berhasil menghentikan rencana makar. Kedua, Soeharto sebagai 'avonturir' yang mengetahui rencana makar tersebut dan melakukan segala tindakan untuk menggagalkan serta mengambil keuntungan atasnya. Kedua narasi memori media ini memenuhi kriteria konsistensi internal (dalam teks). Kelemahannya terdapat pada kurangnya ketepatan eksternal saat dikonfirmasi antarteks. Studi ini menemukan bahwa internet dengan ruang yang nyaris tak terbatas, bukanlah jaminan bagi munculnya narasi memori yang lengkap dan beragam.
\end{abstract}

Kata Kunci: memori media; Soeharto; Gerakan 30 September (G30S)

\begin{abstract}
September 30 Movement (G30S) was a watershed in Indonesia's modern history. Soeharto, as a figure who played a number of strategic actions in 1965, was important to become the object of study, considering that the event which took him over thirty years was in the top of Indonesian power, replacing President Sukarno. During that period, the G30S had become a state propaganda tool. After two decades Soeharto was no longer in power and this event entered the age of half a century, in 2015 a number of Indonesian online news made special reporting to remembering that time. This study based on the premise that the amount of space capacity on the internet and the support of links (hypertext) on the web, including the many references related to the G30S and post-G30S events, enables online news to offer more complete and diverse information. How has Indonesian online news narrated the memory of Soeharto's role and the September 30 Movement after half a century passed? Using the concept of media memory from Motti Neiger et al. and Fisher's Narrative Paradigm theory, this study used the framing method from Pan and Kosicki to analyze 27 articles spread across six Indonesian news sites. It was found that Soeharto was featured in two main narratives. First, Soeharto as a military figure as a 'savior' who managed to stop the plot of the coup. Secondly, Soeharto as 'adventurer' who knew the plot and took all actions to derail and take advantage of it. Both of these narratives meet internal coherence criteria (in text). The weakness is in the lack of fidelity (external accuracy) when confirmed between the texts. This study found that although the internet has almost unlimited space is no guarantee for an emergence of a complete and varied memory.
\end{abstract}


Keywords: media memory; Soeharto; September 30 Movement

\section{Pendahuluan}

Berhentinya Soeharto sebagai Presiden di tahun 1998 tidak hanya mengubah politik Indonesia, tetapi juga pembacaan atas sejarah dan pewarisan memori yang diberikan pada generasi selanjutnya. Selama tiga dekade sejarah digunakan oleh Orde Baru sebagai alat untuk mengukuhkan kekuasaannya. Salah satu yang mencolok adalah penyajian narasi terkait perististiwa Gerakan 30 September (atau G30S). Tiga dekade pemerintahan Soeharto, hanya ada satu narasi tentang G30S yang menyebutkan bahwa Partai Komunis Indonesia (PKI) adalah dalang G30S. Sementara menurut Sulistyo (2011: 5567) sedikitnya ada lima versi skenario terkait siapa yang berada di balik G30S yakni: PKI, Angkatan Darat, Soekarno, Soeharto, serta jaringan intelijen dan CIA (Badan Intelijen Pusat Amerika Serikat).

Sejarawan Asvi Warwan Adam (2015) menyebut turunnya Soeharto tahun 1998 ikut berimplikasi bergantinya narasi tunggal yang selama kurun waktu tersebut mendominasi. Dia mendasarkan penilaiannya pada mulai bersuaranya para pelaku dan penyintas (korban yang berhasil bertahan hidup). Khusus untuk pelaku, Adam menyebut film berjudul "Jagal" (The Act of Killing) di tahun 2012 dan "Senyap" (The Look of Silence) pada tahun 2014 karya Joshua Oppenheimer sebagai penanda era baru tersebut. Untuk memeriksa penilaian Adam tadi, menjadi penting untuk mengetahui cara media massa, khususnya media berita daring (internet) Indonesia, mengenang kembali dan mewariskan memori terkait Soeharto dan G30S setelah setengah abad berlalu.
Media berita daring dipilih karena internet memiliki penetrasi informasi relatif lebih luas, lebih murah, serta lebih praktis dibandingkan dengan media cetak, radio, atau televisi. Hasil survei APJII (Asosiasi Penyelenggara Jasa Internet Indonesia) dan Pusat Kajian Komunikasi Universitas Indonesia tahun 2015 merilis data yang menunjukkan bahwa kecenderungan penggunaan internet terus meningkat. Akhir tahun 2014 mencapai 88,1 juta pengguna dengan mayoritas pengguna berdomisili di pulau Jawa (52 juta) dan Sumatera (18,6 juta). Dapat dikatakan bahwa segmen pengguna internet di Indonesia adalah mereka yang termasuk ke dalam kategori digital natives atau Generasi Z. Data tahun 2015 menyebutkan bahwa mayoritas pengguna internet di Indonesia berusia 18-25 tahun yaitu sebesar 49 persen, menyusul mereka yang berusia 2635 tahun sebesar 33,8 persen. Pemilihan media berita daring (online) ini sekaligus bermaksud untuk mengetahui ragam memori seperti apa yang berpotensi menerpa mereka.

Selain jumlah penggunanya yang terus meningkat, situs berita juga mudah diakses dari berbagai piranti, terkhusus piranti bergarak atau gawai (gadget) karena mendukung segala platform pesan: teks, foto, audio, bahkan audio visual. Data survei 2015 tadi menunjukkan bahwa 85 persen pengguna mengakses internet melalui telepon seluler. Dua dari lima hal utama yang dilakukan para pengguna saat mengakses internet adalah membaca berita serta mencari informasi yang mereka butuhkan - selebihnya mengakses untuk pesan singkat, media sosial, dan menonton video. Seperti yang dilansir Alexa.com (2016), situs berita berada di posisi sepuluh 
besar situs yang tinggi tingkat kunjungannya di Indonesia. Khusus untuk layanan situs berita, salah satu karakter teknologi web yang menjadi kelebihan dari media baru adalah pranala atau hipertaut (hypertext) yang memungkinkan pembaca mendapat beberapa versi ragam artikel di halaman lain yang setema atau memiliki relevansi dengan teks yang sedang dibaca dalam suatu halaman web. Sistem pengarsipan digital dan mudah diakses ini memberi keleluasaan publik untuk mengoptimalkan pencarian informasi yang mereka butuhkan.

Kembali ke momen setengah abad G30S, Soeharto dan peristiwa di sekitar tahun 1965 menjadi penting untuk dikaji karena beberapa alasan. Pertama, karena dalam salah satu versi skenario menyebut bahwa Soeharto berada di balik G30S (Sulistyo, 2011: 62-64). Penting untuk mengetahui bagaimana situs berita menyajikan versi tersebut setelah Soeharto tidak berkuasa lagi. Kedua, sebagai pihak yang memperoleh keuntungan dari G30S dan peristiwa tahun 1965, Soeharto berada dalam posisi yang dapat diduga melakukan serangkaian manipulasi dan dalih untuk melegitimasi segala tindakannya untuk memperoleh kekuasaan menggantikan Presiden Soekarno seperti yang dipaparkan John Roosa (2008). Penelitian ini mengajukan pertanyaan: Bagaimana media berita daring Indonesia menarasikan pewarisan memori atas peran Soeharto dan G30S setelah setengah abad berlalu?

\section{Kajian Literatur}

Pewarisan masa lalu yang dilakukan media massa adalah bentuk kajian dari memori media (media memory). (Neiger, Meyers, \& Zandberg, 2011) menggambarkan memori media sebagai penggunaan secara sistematis masa lalu yang sifatnya kolektif: dinarasikan oleh media, disebarluaskan dengan menggunakan media, dan mengkaji tentang cara media melakukan hal tersebut. Memori media dilihat sebagai bentuk memori kolektif yang termediasi. Salah satu hal yang menjadi perhatian mereka adalah peran media sebagai agen memori. Menurut Neiger dkk (2011: 10-14), peran ini meliputi tiga hal. Pertama, otoritas yang digunakan media dalam menarasikan masa lalu karena di satu sisi mereka memposisikan diri sebagai arena tampat bertemunya beragam agen memori seperti akademisi atau aktivis politik, tetapi di sisi lain mereka juga berperan sebagai agen memori yang menyajikan pembacaan mereka atas masa lalu. Kedua, cara media itu sendiri dalam membatasi apa yang dimaksud sebagai kolektivitas suatu memori. Media massa hanya akan menyajikan sesuatu yang dinilai sebagai "milik bersama". Di sini terlihat cara media menentukan apa saja yang merupakan memori bersama. Ketiga, media memposisikan diri sebagai penjaga konsensus dengan terus menjaga apa yang tadi didefinisikan sebagai memori bersama, atau menawarkan versi lain dari memori yang sudah ada.

Tersampaikan secara naratif adalah salah satu premis dari memori kolektif, yang juga merupakan premis dari memori media (Neiger et al., 2011: 5). Oleh karena itu peneliti tertarik untuk menjadikan aspek teks sebagai fokus kajian. Dalam konteks media massa pun, melihat berita dalam perspektif naratif sudah menjadi salah satu aliran dalam kajian pesan (McQuail, 2010). Bahkan Fulton dan kawan-kawan dalam Narrative and Media mendeskripsikan secara detail 
keterkaitan yang erat antara media dan narasi. Jurnalis atau para pekerja media pada dasarnya mengadopsi cara tradisional manusia saat bercerita. Perbedaanya terletak pada format pesan yang mereka buat karena harus menyesuakan diri dengan karakteristik medium yang digunakan.

Ternarasikan adalah ciri dari memori kolektif. Narasi tersebut makin terstruktur saat disebarluaskan melalui media (memori media). Walter Fisher (1987: 58) mendefinisikan narasi sebagai tindakan simbolik berupa kata dan/atau tindakan yang memiliki rangkaian dan makna bagi mereka yang menyampaikan, menciptakan, atau menginterpretasikannya. Ada lima asumsi dari teori Paradigma Naratif Fisher yang disarikan oleh Griffin:

1. Manusia pada dasarnya adalah penutur kisah (storytellers).

2. Manusia membuat keputusan berdasar pada beragam penalaran yang baik (good reasons) yang bergantung pada situasi komunikasi, media, dan genre (filosofis, teknis, retoris, atau artistik).

3. Sejarah, biografi, budaya, dan karakter ditentukan oleh apa yang kita rujukkan sebagai penalaran yang baik.

4. Rasionalitas naratif ditentukan oleh koherensi (coherence) dan ketepatan (fidelity) dari kisah.

5. Dunia adalah seperangkat kisah yang dipilih oleh manusia dan terus menerus membentuk kembali kehidupan mereka. (Griffin, 2012: 312)

Konsep "penalaran yang baik" yang dikemukakannya dalam asumsi teori ini memandang manusia sebagai makhluk yang rasional. Dengan demikian struktur narasi sedapat mungkin memenuhi kriteria rasionalitas narasi.

... penalaran yang baik berpusat pada lima isu yang terkait ... (1) nilai-nilai yang tertanam dalam pesan, (2) relevansi nilai-nilai tersebut dengan keputusan yang dibuat, (3) konsekuensi dari mengikuti nilai-nilai tersebut, (4) dapat dicocokkan dengan pandangan dunia audiens, dan (5) kesesuaian dengan apa yang diyakini oleh audiens sebagai dasar ideal untuk berperilaku. (Griffin, 2012: 314)

Dalam bentuk kata kunci, Fisher (1987: 109) menyebut kelima aspek ini terkait dengan fakta, relevansi, konsekuensi, konsistensi, dan isu transendental. Oleh karena paradigma ini melihat manusia sebagai makhluk rasionl, narasi yang disampaikan pun harus memenuhi kriteria rasionalitas naratif yang ditentukan oleh koherensi dan ketepatan pesan yang disampaikan. Koherensi naratif merujuk pada konsistensi internal atas satu informasi dengan informasi lain dalam narasi. Sementer yang ia maksud sebagai ketepatan naratif adalah kesesuaian antara nilai-nilai yang tertanam dalam sebuah pesan dan apa yang dianggap sebagai suatu kebenaran.

Narasi berita sebagai hasil dari tindakan simbolik jurnalis memiliki relevansi dengan asumsi-asumsi Fisher ini. Sebagai manusia, jurnalis pada dasarnya adalah seorang penutur kisah. Agar argumentatif, berita yang mereka buat sedapat mungkin dikemas agar dapat memenuhi kriteria rasionalitas naratif tadi. Hal ini penting karena berita sebagaimana layaknya pesan komunikasi yang lain - akan digunakan untuk pengambilan keputusan. McQuail (2010) mengemukakan, diskusi Cappella dan Jamieson yang mengindikasikan bahwa narasi yang menyediakan seluruh informasi kunci dalam satu halaman web, lebih menggiring publik untuk berpikir dengan menggunakan rute sentral (secara kritis) dibandingkan yang menyediakan informasi tersebut di halaman web yang berbeda. Sebaliknya, publik cenderung 
menggunakan rute tepi (berpikir ringkas) ketika informasi atau fakta yang dibutuhkan tidak tersedia di dalam satu halaman web. Data tersebut bisa jadi tersimpan di halaman lain yang mungkin terhubung atau tidak dengan pranala. Narasi seperti ini berpeluang dalam mempengaruhi publik melalui framing dan priming. Dengan kata lain, narasi yang tidak menyediakan informasi kunci, atau meminjam istilah Fisher, tidak memenuhi kriteria rasionalitas naratif.

Menurut Bell dan Garrett (dalam Fulton et al, 2005: 227-228), jurnalis pada dasarnya tidak membuat tulisan (articles), mereka menulis kisah (stories) dengan struktur, urutan, sudut pandang dan nilainilai tertentu. Darnton (berpendapat bahwa berita dihasilkan melalui cara lama menuturkan kisah. Laporan berita biasanya ditampilkan dalam bentuk narasi dengan aktor utama dan sampingan, urut-urutan yang saling berhubungan, pahlawan dan penjahat, babakan awal-tengah-akhir. Itu semua menandakan kejadian dramatis dan bersandar pada alur cerita yang familiar (McQuail, 2010).

Michael Schudson (2005: 121) berpendapat bahwa berita juga merupakan sebuah kisah, meski dalam kesempatan yang bersamaan juga adalah sebuah laporan peristiwa. Oleh karena itu, publik mengharapakan berita memiliki awal, tengah, dan bagian akhir dan berjalan menurut suatu standar prosa naratif. Bagi Bird dan Dardenne, berita sebagai narasi membantu untuk memaknai pelaporan pengalaman jurnalis (McQuail, 2010).

Baik itu dalam bentuk menghubungkan tindakan dan peristiwa dalam cara yang logis, berurutan serta timbal balik, atau (2) dengan menyediakan elemen orang dan tempat yang memiliki karakter tetap dan dapat dipahami karena realistis. Narasi membantu memberikan logika dari motif manusia yang memaknai pengalaman tersebut secara terpisah.

Secara garis besar, Schudson (2005: 126) mengutip pendapat James Carey yang menunjukkan cara tertentu yang digunakan untuk menjelaskan atau menambahkan penjelasan atas suatu peristiwa. Pertama, dengan mengemukakan motif. Setiap tindakan pasti memiliki agen. Setiap agen pasti memiliki tujuan. Tujuan tersebut yang kemudian digunakan untuk menjelaskan tindakan. Saat mengangkat topik seperti politik, cara ini jamak ditemukan dalam berita. Jika teknik menjelaskan seperti ini tampak kurang cukup memberi penjelasan atas suatu tindakan atau kejadian, jurnalis dapat menggunakan cara kedua yaitu melihat dari sudut pandang penyebab yang secara sosial atau institusional menjadi kekuatan yang memaksa suatu peristiwa hingga dapat terjadi. Sudah menjadi sebuah konsensus yang tidak terucapkan bahwa jurnalis dapat menggunakan otoritasnya untuk menjelaskan suatu motif, namun jika mereka menggunakan pendekatan penyebab, jurnalis harus menemukan ahli yang dapat mengurai suatu kasus.

Praktik menyajikan berita secara narasi oleh Bird dan Dardenne dinilai dapat berimplikasi pada penerimaan berita itu sendiri menjadi sebentuk mitos. Mitos ini yang menjadi rujukan nilai, mendefinisikan baik dan buruk. Berita menjadi sumber informasi utama atas kontur normatif masyarakat. Menyajikan parameter tentang apa yang selayanya dihindari, termasuk tentang asumsi perbuatan apa yang tergolong buruk. Berita menjadi semacam galeri di mana pahlawan dan orang suci dapat berdampingan dengan penjahat dan 
pelaku tindak tercela lainnya. Tidak tentang rujukan nilai saja, tetapi dengan lebih rinci mengutip hasil studi sejumlah ilmuwan, mereka mengemukakan:

Berita menawarkan lebih dari fakta berita menawarkan ketentraman hati dan keakraban dalam berbagi pengalaman bersama di masyarakat... berita memberikan jawaban yang kredibel untuk pertanyaan yang membingungkan dan menyiapkan penjelasan untuk fenomena yang kompleks ... Karena melalui ritual berkisah (termasuk berita), mitos diperankan, ditransformasaikan, dan diciptakan kembali dalam "proses ritual". Sebagai sistem simbolis, mitos dan berita bertindak baik sebagai model dari dan untuk budaya ... (Bird \& Dardenne, 1997)

Dalam konteks memori media, ulasan Bird dan Dardenne menunjukkan bahwa berita dapat menyajikan memori kolektif menjadi mitos karena jurnalis tidak saja menarasikan sesuatu "seperti apa adanya", tetapi menyajikannya menjadi "seperti apa maknanya". Interpretasi selalu hadir di setiap narasi.

Berita dapat disebut sebagai mitos karena mengangkat "kisah dari sesuatu yang signifikan" (Segal, 2004: 5). Berita dibangun oleh asumsi bahwa apa saja yang diwartakan adalah sesuatu yang penting. Anggapan bahwa mitos sebagai sesuatu yang benar atau salah tidak menjadi perhatian para ilmuwan yang menggeluti topik ini. Tidak jarang, mitos yang diyakini kesalahannya pun tetap dipegang dengan erat. Bahkan bisa jadi, mitos yang salah tersebut dianut lebih kuat daripada kebenaran yang lain. Ada dua pandangan atas mitos - yang dapat digunakan dalam konteks studi memori media. Pertama, pandangan yang ingin membongkar kepalsuan dari mitos jika penjelasan yang diberikan tidak sesuai dengan ilmu pengetahuan. Kedua, pandangan yang tidak mempersoalkan kebenaran atau kepalsuan dari mitos yang ada tapi lebih pada mempertimbangkan atau menganggap mitos sebagai sesuatu yang dapat diterima dan mungkin juga diperlukan oleh semua masyarakat (Segal, 2004). Pandangan pertama lebih bersifat kritis, sementara yang kedua lebih bersifat fungsional.

Kembali dalam kaitan antara berita dan mitos, meski telah didefinisikan dalam banyak bentuk, definisi-definisi tentang mitos selalu mengarah pada fungsinya dalam menyediakan narasi yang kuat untuk membentuk kesadaran kontinum atas tatanan dunia, terlepas dari apakah narasi tersebut menggambarkan sesuatu yang sifatnya fiksi atau nyata. Berita menjalankan fungsi sebagai mitos. Ia menyampaikan kisah yang menjelaskan suatu fenomena dan menyediakan jawaban yang dapat diterima untuk itu. Mitos tidak dibutuhkan sebagai bentuk refleksi atas suatu realitas obyektif, tetapi membangun penjelasan sendiri atas dunia yang digambarkannya. Fungsi dari mitos adalah menjelaskan apa saja yang tidak mudah untuk dijelaskan, terkhusus yang sifatnya abstark (tidak terukur) seperti moralitas, kepantasan, atau kejujuran. Mitos memiliki kemiripan dengan berita yaitu dengan gaya naratif memenuhi kebutuhan manusia yang tidak mudah toleran atas hal yang sifatnya acak dan tidak dapat diprediksi, sulit dipahami, penuh ketidakpastian dan ambiguitas. Berita sama seperti mitos, memberi kenyamanan dengan penjelasanpenjelasan serta memberi ruang kendali atas apa yang ada disekitar kita (Bird \& Dardenne, 2009).

\section{Metode Penelitian}

Teks dan konteks, sebagaimana dikemukakan tadi pada prinsipnya juga menjadi bagian dari riset memori media. 
Baik konteks yang pertama maupun yang kedua, keberadaannya dapat dilacak melalui teks yang dipublikasikan media. Khusus untuk pola hubungan dari satu atau lebih teks, secara teknis dapat dilacak melalui pranala yang tersedia di situs berita. Keberadaan pranala, selain menyediakan ruang informasi untuk kelengkapan dari setiap narasi, ia juga menuntukan keterhubungan tematik antara satu teks dengan teks lainnya. Penelitian ini memusatkan perhatian pada narasi tentang Soeharto dan peristiwa tahun 1965 yang terpublikasikan setengah abad setelah peristiwa tersebut berlalu. Sampel yang menjadi obyek dipilih memiliki dua kriteria. Pertama, mengangkat tema tentang G30S dan Peristiwa 1965 dengan kriteria (1) Soeharto sebagai tokoh utama penuturan, (2) menyebutkan Soeharto dalam latar kisah (setting), atau (3) tokoh lain termasuk peristiwa yang disebutkan memiliki kaitan dengan Soeharto dalam alur kisah (plot). Semua pranala yang tersedia dalam setiap halaman web, ditelusuri jalur dan substansinya. Hanya yang sesuai dengan dua kriteria sampel yang juga akan digunakan sebagai obyek penelitian. Kriteria kedua, adalah artikel tersebut terpublikasikan pada momen Setengah Abah G30S di situs-situs berita Indonesia selama kurun waktu September November 2015. Perpanjangan waktu hingga November 2015 dilakukan dengan pertimbangan bahwa di awal bulan tersebut digelar International People's Tribunal di Den Haag (Belanda) yang mengugat para pihak yang dianggap bertanggung jawab atas Peristiwa 1965.

Selama kurun waktu tersebut, ditemukan 27 artikel narasi. Artikel yang berbahasa Indonesia ini tersebar di sejumlah situs berita. Ada yang secara khusus dikelompokkan dalam satu kategori berita dengan tema "50 Tahun G30S" atau "Setengah Abad G30S", ada pula yang tidak. Terdapat enam situs berita yang menjadi sumber artikel yaitu: Tempo.co (13 artikel), Merdeka.com (4 artikel), Gatra.com (3 artikel), CNN Indonesia (3 artikel), BBC Indonesia (2 artikel), dan Kompas.com (2 artikel). Penelitian ini hanya memusatkan perhatian pada teks yang ditampilkan oleh seluruh situs berita tersebut. Identitas media bukan menjadi titik tekan karena pengguna internet mengkonsumsi media daring tidak berdasarkan pada penyedia layanan beritanya, tapi pada isu yang mereka minati dan umumnya direkomendasikan oleh 'mesin' jurnalisme daring (Flew, 2014). Imam Wahyudi dalam diskusi "Media dan Opini Publik" di Universitas Indonesia (Depok, 30 November 2018) juga menyatakan, studi yang dilakukan oleh Dewan Pers mengindikasikan bahwa menjadi tidak relevan lagi saat ini ketika memperhadapkan antara media daring besar dan kecil, media massa dan media sosial. Sebuah isu yang diangkat media daring besar justru berawal dari media daring kecil dan bermula dari publikasi di media sosial. Intinya terletak pada isu, bukan pada medianya.

Internet bekerja menurut algoritme dengan cara merekomendasikan sejumlah berita yang paling banyak dibaca. Peneliti media dari Universitas Queensland, Dan Angus dalam sebuah kuliah umum di Universitas Indonesia (12 Juli 2017) menjelaskan untuk kasus berita, 40 persen artikel yang dikonsumsi oleh pengguna internet adalah hasil rekomendasi dari Google. Selebihnya diambil alih oleh aplikasi penyedia ragam berita (news aggregator). Dalam sebuah diskusi 
kelompok terfokus di bulan Mei 2017 yang dilakukan peneliti atas beberapa pembaca berita daring (online) di rentang usia 18-25 tahun ditemukan bahwa aplikasi penyedia ragam berita (seperti Baca Berita atau Line) dinilai lebih praktis dan memiliki ragam pilihan informasi. Mereka bahkan tidak mengetahui dari situs mana berita tersebut berasal. Para pengguna lebih terfokus pada isu yang menarik perhatian atau yang dianggap penting.

\section{Hasil dan Diskusi}

Memori dalam narasi media berita daring Indonesia dapat dikelompokkan ke dalam beberapa fragmen topik yang berkaitan dengan Soeharto, G30S dan Peristiwa 1965. Pertama, Soeharto hadir dalam gambaran umum G30S yang disebutkan memimpin serangan balasan yang cepat dan efisien, serta menumpas para perencana aksi dalam waktu 24 jam. Kedua, dalam liputan media asing, Soeharto disebutkan sebagai orang kuat antikomunis dari kubu kontra G30S atau antikomunis. Ketiga, artikel bersudut pandang Inggris dan Amerika Serikat menyebutkan Soeharto mampu menggagalkan upaya kudeta yang kemudian dimanfaatkan oleh kedua negara tersebut. Ia pada akhirnya mampu menggantikan Presiden Sukarno. Keempat, dalam artikel yang berkaitan dengan dokumen CIA, Soeharto disebutkan memiliki kecenderungan yang pro Barat dan menuding Angkatan Udara ikut terlibat G30S. Ia juga mendapat bantuan dari Dubes AS, Marshall Green dan menjadi aktor dalam menggulingkan Presiden Sukarno. Fragmen berikutnya atau yang kelima adalah yang berkaitan dengan Tiongkok. Soeharto disebutkan memimpin propaganda antikomunis di tubuh Angkatan Darat (AD) yang menuding peran besar
Peking atau Republik Rakyat Tiongkok di balik skenario kudeta PKI.

Fragmen keenam yang menyiratkan Soeharto menjadi bagian dari skenario G30S adalah ketika ia dikatakan bersekongkol dengan Sukarno yang dituding sebagai inspirator utama G30S. Meskipun pada akhirnya ia disebutkan mengkhianati Sukarno. Tidak terkecuali menentang keputusan Presiden Sukarno terkait penunjukkan Mayjen Pranoto sebagai Pelaksana Harian Pimpinan AD. Ketujuh, fragmen yang memuat kesaksian Omar Dani menyebutkan bahwa G30S adalah sebuah rekayasa yang melibatkan Soeharto, Nasution, dan CIA. Fragmen kedelapan dapat dikatakan sebagai bagian yang mempertegas pernyataan fragmen sebelumnya. Sebelum G30S, Soeharto disebutkan mengetahui Untung terlibat dalam Peristiwa Madiun 1948 dan menempatkan Untung di Tjakrabirawa. Ia juga mengetahui rencana G30S yang dipimpin Untung dan membantu Untung saat G30S dengan mengirim pasukan. Secara personal, Soeharto juga dikatakan dekat dengan Untung baik di dalam maupun di luar lingkungan militer sebelum G30S. Ini yang menjadi peneguh bahwa Soeharto ada dalam skenario G30S. Fragmen kesebilan yang mengaitkan Soeharto dengan persekusi pasca-G30S terindikasi dari: 1) ia menangkap dan menahan Pranoto dengan tuduhan terlibat G30S; 2) tersirat bahwa Soeharto yang memerintahkan penangkapan Gubernur Bali Sutedhja meski Presiden Sukarno sudah menegaskan bahwa Sutedhja tidak tahu dan tidak terlibat G30S; 3) pembunuhan massal baru terjadi setelah kedatangan satuan khusus militer, dikirim ke desa-desa oleh Soeharto; dan 4) Soeharto tidak terbukti berhasil mencegah 
pembunuhan massal sebagaimana yang ia laporkan kepada Presiden Sukarno.

Meski berupaya menempatkan Soeharto pada pusat narasi G30S, artikel yang ditampilkan situs berita dalam mengenang "Setengah Abad G30S" seolah membagi narasi pada PKI dan keterlibatan badan intelijen Amerika Serikat (CIA) dan Inggris (MI6). Uraian keterlibatan Presiden Sukarno yang justru tersaji lebih rinci namun hanya dimuat dalam satu artikel. Sementara skenario tentang G30S sebagai masalah internal AD sama sekali tidak muncul. Skenario tentang Soeharto memang tampil, tetapi dalam potonganpotongan informasi yang tidak tegas di sedikitnya lima artikel. Boleh jadi karena Soeharto tampil sebagai 'pemenang' dalam pertarungan kekuasaan tahun 1965-1966, ia kemudian terlihat masuk akal ketika digiring masuk pusat narasi sebab dapat beririsan dengan empat skenario yang lainnya (seperti yang tampak dalam Gambar 1).

\section{Gambar 1}

Soeharto dalam Irisan Skenario G30S di Situs-situs Berita Indonesia (September-

November 2015)

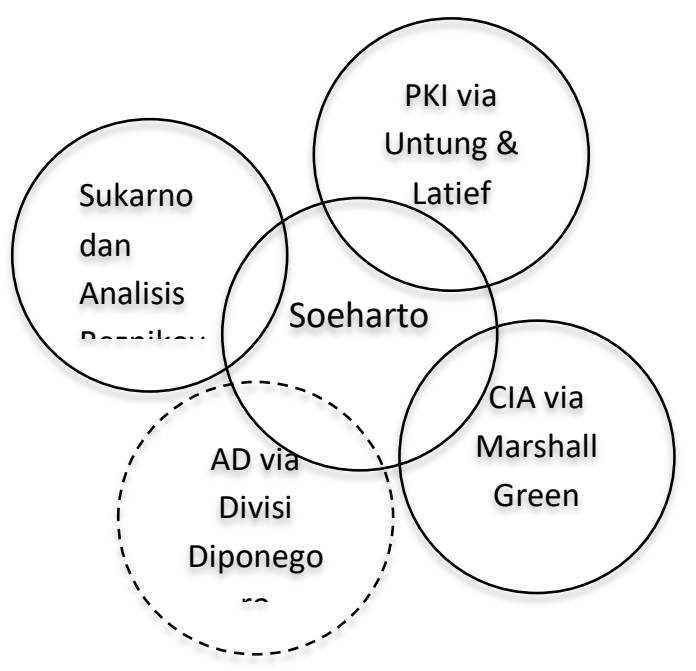

Sumber: Olahan Data Primer (2018)

Keterangan:

__ : media menyatakan secara eksplisit

- - - - : media menyatakan secara implisit

Media berita daring menggambarkan bahwa sejak memimpin Divisi Diponegoro di Semarang (Jawa Tengah), Soeharto memiliki hubungan dengan aktor lapangan G30S yaitu Untung dan Latief. Kehadiran divisi ini juga yang secara implisit mengaitkan Soeharto dengan skenario G30S sebagai pertarungan internal AD. Meski demikian, skenario G30S dan pertarungan internal AD ini benar-benar tak pernah dipaparkan secara gamblang oleh situs berita.

Sedikitnya ada lima tokoh kunci G30S yang ditangkap: Syam, Supono, Untung, Latief, dan Sujono. Satu-satunya pemimpin kunci G30S yang tidak dihukum mati adalah Latief — namun media berita daring tidak tertarik menggalinya. Di sisi lain, Latief adalah simpul yang juga membangun teori keterlibatan Soeharto dalam G30S. Menurut (Roosa, 2008), Latief menolak menjelaskan G30S secara rinci. Dia juga tidak menggunakan kesempatan di depan pengadilan pada 1978 untuk menjelaskan cara mereka mengorganisasi G30S. Pidato pembelaannya menjadi terkenal dan tersebar luas karena satu pernyataannya yang mengejutkan bahwa ia telah memberi tahu Suharto tentang gerakan itu sebelumnya. Roosa juga menilai bahwa sebagian besar pidato pembelaannya tercurah pada cekcok yang relatif tidak penting tentang keterangan para saksi, atau pada penjelasan riwayat hidupnya untuk membuktikan diri sebagai prajurit yang patriotik. Sesudah 1978, Latief tidak pernah menyimpang dari pembelaannya dan juga 
tidak pernah mengurai lebih lanjut pernyataan-pernyataannya. Bahkan juga sesudah dibebaskan dari penjara pada 1998, Latief tidak memberikan keterangan baru satu patah kata pun.

Alih-alih mengulas Latief, sorotan media berita daring lebih tertuju pada hubungan antara Untung dan Soeharto. Meski (Tempo, 2015) mengakui bahwa kedekatan keduanya adalah sebuah spekulasi yang jarang diulas, jalinan tersebut dibangun oleh media sedikitnya melalui lima argumentasi. Pertama, pernyataan Soebandrio yang menuturkan kembali kisah Untung kepadanya saat ditahan bersama pasca-G30S. Kedua, informasi dari Letkol CPM (Purnawirawan) Suhardi, sahabat masa kecil Untung di Solo dan bekas anggota Tjakrabirawa, yang menyebut Soeharto adalah atasan Untung saat masuk masuk Korem Surakarta. Ketiga, penilaian Kolonel Purnawirawan Maulwi Saelan (mantan Wakil Komandan Tjakrabirawa, atasan Untung), Untung adalah anak kesayangan Yani dan Soeharto setelah sukses dalam penumpasan pemberontakan PRRI/Permesta dan Operasi Mandala. Keempat, informasi dari Letkol CPM (Purnawirawan) Suhardi yang menyebut Soeharto yang merekomendasikan Untung untuk masuk Tjakrabirawa. Kelima, hadirnya Soeharto dalam pesta pernikahan Untung yang diungkapkan oleh Syukur, tetangga istri Untung.

Menurut Hermawan Sulistyo, skenario Soeharto berada di balik G30S dikemukan oleh WF Wertheim. Dalam tulisannya berjudul Soeharto and the Untung Coup, Wertheim menyatakan bahwa Syam lebih mungkin sebagai agen Soeharto yang menyusup ke dalam tubuh PKI, ketimbang orang PKI yang menjadi informan AD. Dengan kata lain, Wertheim ingin mengatakan bahwa jejak tangan Soeharto dapat ditelusuri melalui Syam Kamaruzaman. Dalam sebuah artikel yang diangkat Tempo.co (2015a) berjudul G30S 1965: Lelaki Lima Alias di Operasi Penculikan, digambarkan Syam sejak muda sudah bersimpati pada gerakan Kiri, bergaul rapat dengan kelompok pemuda Pathuk yang rata-rata beraliran sosialis di Yogyakarta, serta aktif dalam perang melawan Belanda dan Jepang. Di sisi lain, kelompok pemuda Pathuk ini pula yang kemudian disebut-sebut sebagai awal mula kedekatan Soeharto dan Syam. Saat menulis tentang Siapa Sebenarnya Soeharto: Fakta dan Kesaksian Para Pelaku Sejarah G30S/PKI, Eros Djarot dan kawan-kawan menyebutkan bahwa keduanya pernah bertemu dalam forum orang-orang Kiri yang kemudian dinamakan "Kelompok Pathuk", di Yogyakarta. Pada 1968 dikabarkan Syam ditangkap dan dijatuhi hukuman mati. Tapi pada awal 1980, dia tampak keluar-masuk di berbagai instansi militer. Menurut seorang mantan perwira Kopkamtib, Syam memang dipakai sebagai informan militer. Latief bahkan mengakui, pada tahun 1990 ia berjumpa dengan Syam di Cipinang. Padahal Syam telah dieksekusi mati pada September 1986. (Djarot, 2006)

Seorang aktivis Pathuk pernah menyatakan bahwa perkenalan antara Syam dan Soeharto sebatas perkenalan biasa dan tidak intensif. Itu terjadi ketika para pemuda Pathuk berhasil mencuri senapan darai tangsi militer Jepang sebulan setelah setelah Proklamasi Kemerdekaan. Banyaknya senapan yang yang disita akhirnya mereka bekerja sama dengan Letnan Kolonel Soeharto yang saat itu menjabat sebagai Komandan Resimen di Yogyakarta (Tempo, 2008h). Menurut Anton Ngenget, Soeharto masuk kelompok 
Pathuk. Ia seangkatan dengan Syam Kamaruzaman. Untung juga direkrut, tapi klasifikasinya di bawah Soeharto, sebab dia bukan perwira (Djarot, 2006). Kelompok Pathuk itu adalah kelompok pemuda yang mengadakan pertemuan di jalan Purwanggan Yogyakarta, tempat kos waktu sekolah di Sekolah Menengah Teknik (SMT) Kota Baru. Embrionya telah ada sewaktu zaman Jepang tahun 1943. Mulamula terdiri dari empat orang, yaitu Kusurno Sunjoyo, Perrnadi Joy (SMT), Nyoto (SMT), dan Dayno. Anggotanya terdiri dari orang-orang yang sudah bekerja, tamatan SMT, masyarakat yang sekolah atau tidak sekolah, termasuk sopir bahkan preman. Menurut Dayno, kelompok ini sebenarnya hanya memberikan pengertian politik berkenaan dengan persiapan kemerdekaan setelah pengambilalihan kekuasaan dari Jepang. Soeharto baru bergabung dengan kelompok Pathuk nanti setelah kemerdekaan. Tidak sampai setahun, hanya bulanan. Boleh dikata Soeharto tidak terlibat di Pathuk. Hubungan dengan Syam didasarkan dengan perkenalan Syam sebagai orang Pathuk. Bukan hubungan politik. Hubungan Syam dengan Soeharto sama dengan hubungannya terhadap sesama anggota kelompok Pathuk (Djarot, 2006).

Tentang kelompok Pathuk ini, Des Alwi juga memberi kesaksian. Pathuk adalah tempat berkumpulnya para pemuda pergerakan kemerdekaan yang ada di Yogyakarta. Di sana Des Alwi bertemu Soeharto. Sosok yang digambarkannya sebagai orang yang tak banyak bicara, cerdas, kalem, tapi dengan wajah yang tampan ia sangat mudah menarik perhatian orang-orang di sekitarnya. Des Alwi bertemu Soeharto di Pathuk tak lama setelah Proklamasi Kemerdekaan. Kala itu
Soeharto baru saja kembali dari Jakarta setelah keluar dari dinas KNIL (Koninklijk Nederlandsche Indie Leger). Menurut Des Alwi, "Peran Soeharto muda dalam perjuangan kemerdekaan di Yogyakarta sangat menonjol. Kami pernah bersamasama ketika mencuri senjata untuk keperluan perjuangan. Kami berangkat ke Surabaya, namun tampaknya ia tibak begitu menyukai suasara perjuangan di sana, maka kami pun kembali ke Yogyakarta. Sempat pula saya ke sejumlah kota di Jawa Tengah, Jawa Barat, dan Jakarta untuk membeli senjata yang dibutuhkan pasukan Soeharto" (Alwi, 2011: 55-56). Dia tidak menyinggung soal aktivitas politik Soeharto dan kelompok Kiri yang ada di Pathuk. Des Alwi berkisah bahwa pertemuan selanjutnya dengan Soeharto saat menjalin hubungan diplomatik dalam normalisasi hubungan dengan Malaysia pasca Peristiwa 1965.

Kembali ke kaitan antara Soeharto dan tokoh-tokoh G30S, WF Wertheim juga mengemukakan bahwa Soeharto memiliki hubugan dengan semua perwira penting $A D$ yang terlibat dalam G30S yaitu: Untung, Latief, dan Soepardjo. Namun tulis Sulistyo - dengan mengutip Harold Crouch, bukti seperti ini tidak cukup untuk mendukung pendapat bahwa Soeharto terlibat dalam persekongkolan para perwira tersebut.

Spekulasi mengenai peran Soeharto dalam rencana dan pelaksanaan Peristiwa Gestapu muncul ketika ia membuat cerita yang tidak konsisten mengenai perjumpaannya dengan Latief. Akan tetapi, tidak ada bukti lain yang mendukung versi ini selain perjumpanan singkat Soeharto dengan Latief di rumah sakit dan hubungan masa lalunya dengan beberapa "perwira progresif" dari Jawa Tengah (Sulistyo, 2011).

Kesimpulan serupa juga dikemukakan oleh (Roosa, 2013) yang menyatakan bahwa 
"Bagaimanapun juga tidak ada bukti bahwa Soeharto adalah dalang dari gerakan ini. Justru, bukti yang ada menunjukkan bahwa dia bukan dalangnya". Jadi dapat dipahami mengapa situs berita kesulitan dalam mengkonstruksi hubungan antaran Soeharto dan G30S. Pertama, media tidak mejadikan WF. Wertheim sebagai sumber utama. Kedua, historiografi yang tersedia tidak mencukupi untuk menarik kesimpulan tersebut dengan tegas antara keduanya. Judul yang secara langsung menyebutkan nama Soeharto tidak begitu saja akan menunjukkan bahwa narasinya akan berkisah tentang Soeharto apalagi menjawab pertanyaan atau asumsi yang tersirat dari judul tersebut. Dalam artikel berjudul Omar Dani: CIA Terlibat G30S 1965 dan Soeharto yang Dipakai (Tempo, 2015d), tidak ada satu kalimat pun yang dapat dimaknai sebagai penjelas apa yang telah disebutkan dalam judul. Narasi yang termuat dalam artikel hanya berkisah tentang keheranan Omar Dani atas mereka yang menjadi targer penculikan.

Narasi Soeharto dan G30S, secara keseluruhan artikel di situs berita seolah berhenti pada isu pembunuhan massal. Media tidak memberikan tawaran perspektif bahwa G30S adalah sebuah pertarungan politik antara Soeharto dan Presiden Sukarno. Termasuk perspektif lain yang sudah lebih dulu ditawarkan oleh John Roosa dalam Dalih Pembunuhan Massal: Gerakan 30 September dan Kudeta Suharto menyebutkan bahwa G30S adalah alasan yang digunakan untuk 'membersihkan' komunis dari Indonesia. Peristiwa ini semata-mata dilihat sebagai aksi kudeta dan kontra kudeta. Di sini Soeharto ditampilkan sebagai aktor yang memainkan dua peran sekaligus: protagonis dan antagonis. Pertama, Soeharto ditampilkan sebagai tokoh militer 'penyelamat' yang berhasil menghentikan rencana makar. Kedua, ia dicitrakan sebagai 'avonturir' yang mengetahui rencana makar tersebut sambil mempersipkan diri untuk menggagallkan dan mengambil keuntungan atasnya. Keterlibatannya dalam penangkapan orangorang yang dituduh terlibat G30S dan pembunuhan massal anggota PKI dan organisasi yang berafiliasi dengannya, dapat dilihat dari dua perspektif ini.

Kedua 'wajah' ini ditampilkan bergantung pada sumber yang digunakan oleh media. Mereka yang pro-Soeharto mendudukkan tindakan Soeharto sebagai aksi patriotik, penangkapan dan pembunuhan massal dilihat sebagai konsekuensi yang tak terelakkan. Sementara mereka yang kontra-Soeharto, mencurigai tindakan tersebut sebagai aksi ambil untung yang menghalalkan segala cara untuk menggulingkan Presiden Sukarno -meski harus dengan menumpahkan darah orang yang dituduh terlibat G30S dan berideologi komunis. Sebagai contoh, informasi yang bersumber dari dokumen CIA akan menggambarkan Soeharto sebagai pahlawan. Sementara pernyataan yang dikemukakan tokoh yang dituduh terlibat G30S (seperti Soebandrio dan Omar Dani) berisi perspektif antiSoeharto. Tidak semua narasumber bersikap hitam-putih, sebab ada pula sejumlah narasumber yang oleh media lebih dibutuhkan pernyataan informatif dari mereka, seperti dari John Roosa atau Adam Hughes Henry.

Mereka ini adalah agen memori. Sumber yang digunakan media adalah para pihak yang mengkonstruksi dan memilih memori yang disampaikan. Jurnalis adalah pihak yang utama dalam merangkai sebuah artikel menjadi satu kesatuan narasi. Para jurnalis ini yang kemudian memilih sejumlah sumber yang akan mereka kutip 
atau gunakan pernyataannya. Ada yang dalam bentuk wawancara langsung dengan para saksi mata, ada pula yang menggunakan sumber sekunder seperti buku atau artikel jurnal yang telah ditulis oleh sumber tersebut. Nama sejarawan seperti Asvi Warman Adam atau John Roosa muncul lebih dari dua kali sebagai rujukan agen memori. Beberapa nama lain juga disebutkan seperti Baskara $\mathrm{T}$. Wardaya dan Petrik Matanasi, kemudian Benedict Anderson, Ruth McVey, Antonie Dake, atau Victor Miroslav Fic serta Tim Weiner. Dua sumber yang juga muncul dan menjadi bagian dari Peristiwa 1965 adalah Omar Dani, Soebandrio, dan Soeharto. Meski demikian, terdapat kecenderungan yang menunjukkan bahwa jurnalis mengambil peran sebagai agen memori dengan memasukkan pengatahuannya atas suatu topik. Mereka hanya menjadikan pendapat sumber sebagai pelengkap atas apa yang mereka tidak ketahui.

Walau terlihat memiliki alur bingkai yang sinkron, tidak demikian adanya dengan kualitas narasi yang ditampilkan oleh media terkait memori atas Soeharto dalam konteks 1965, khususnya G30S. Jika ditilik dengan menggunakan pendekatan rasionalitas naratif, ada dua elemen yang tidak sepenuhunya dipenuhi oleh artikel-artikel tesebut. Pertama, konsistensi internal (koherensi) dari pesan yang dapat dicek melalui kesesuaiannya secara intrateks. Kedua, ketepatan atau akurasi pesan jika dilihat secara antarteks. Lemahnya konsistensi antarteks menunjukkan bahwa setiap narasi hanya kokoh secara argumentasi jika dibaca secara terpisah. Ini juga yang dapat menjadi penjelas kurangnya pranala antarteks yang dapat menghubungkan pembaca dari satu narasi ke narasi lain. Tidak tersedianya tautan tersebut di satu sisi memang mengungkung wawasan pembaca, tetapi di sisi lain dapat menjadi peneguh argumentasi yang sedang dibangun oleh suatu narasi. Media lebih menitik beratkan perhatiannya pada konsistensi internal karena aspek ini mudah terlacak jika terdapat ketidak sesuaiannya ide, fakta, atau interpretasi. Publik yang memiliki keterlibatan tinggi atas Peristiwa 1965 memiliki sejumlah pengetahuan awal yang dapat mengkritisi atau mengkonfirmasi data, fakta, atau interpretasi atasnya. Proses ini tidak akan terjadi bagi mereka yang memiliki tingkat keterlibatan yang rendah. Narasi yang saling terpisah (tidak terhubung dengan pranala satu sama lain) makin menggiring publik pada perspektif yang sempit saat melakukan pembacaan.

\section{Simpulan}

Secara ringkas dapat digambarkan bahwa dalam konteks G30S dan Peristiwa 1965 media berita daring Indonesia menarasikan Soeharto sebagai aktor yang memainkan dua peran sekaligus: protagonis dan antagonis. Pertama, Soeharto ditampilkan sebagai tokoh militer 'penyelamat' yang berhasil menghentikan rencana makar. Kedua, ia dicitrakan sebagai 'avonturir' yang mengetahui rencana makar tersebut sambil mempersipkan diri untuk menggagallkan dan mengambil keuntungan atasnya. Keterlibatannya dalam penangkapan orangorang yang dituduh terlibat G30S dan pembunuhan massal anggota PKI dan organisasi yang berafiliasi dengannya, dapat dilihat dari dua perspektif ini. Kedua 'wajah' ini ditampilkan bergantung pada sumber yang digunakan oleh media. Mereka yang pro-Soeharto mendudukkan tindakan Soeharto sebagai aksi patriotik, 
penangkapan dan pembunuhan massal dilihat sebagai konsekuensi yang tak terelakkan. Sementara mereka yang kontraSoeharto, mencurigai tindakan tersebut sebagai aksi ambil untung yang menghalalkan segala cara untuk menggulingkan Presiden Soekarno - meski harus dengan menumpahkan darah orang yang dituduh terlibat G30S dan berideologi komunis.

Soeharto dibingkai dalam lima kategori besar. Pertama, situs berita menampilkan posisi Soeharto dalam Peristiwa G30S, khususnya para tokoh yang ada dalam lingkar peristiwa tersebut. Kedua, analisis yang seorang Direktur Pusat ASEAN di Universitas MGIMO Moskow tentang Soeharto yang digunakan oleh Soekarno dalam G30S. Artikel ini meyakini bahwa Soeharto memiliki kesepakan dengan Presiden Soekarno sebagai aktor intelektual G30S. Ketiga, situs berita menampilkan publikasi yang bersumber dari dokumen CIA (agen intelijen Amerika Sertikat) dan ulasan yang menjelaskan keterkaitan CIA dan dukungannya kepada Soeharto. Keempat, analisis tentang kegagalan G30S. Terakhir atau yang kelima adalah topik yang mengangkat pembunuhan massal pascaG30S yang menempatkan Soeharto sebagai pihak yang paling bertanggung jawab. Meski meletakkan Soeharto dalam lima bingkai tersebut, alih-alih membeberkan berbagai versi historiografis tentang G30S, media berita daring lebih tertarik pada mempertahankan 'konsensus' bahwa PKI sebagai dalang aksi tersebut.

Historiografi yang menyebutkan G30S sebagai bentuk konflik internal Angkatan Darat bahkan tidak muncul sama sekali. Versi ini hanya dapat terbaca secara implisit. Meski mencoba mengangkat juga versi tentang Soeharto, Soekarno, serta
CIA, namun secara umum narasi yang mengemukan tetap mengaitkan G30S dengan PKI. Walau berupaya mengakomodasi beberapa versi alternatif, kekuatan narasinya tidak mendukung. Latief tidak dianggat sebagai sumber oleh media dan ini menjadi salah satu hal yang melemahkan argumentasi keterkaitan antara Soeharto dan G30S. Dialah yang sebenarnya menjadi simpul penting. Keberadaan Latief ini juga yang digunakan oleh WF Wertheim sebagai salah satu dalil tentang keterlibatan Soeharto. Lemahnya kualitas informasi yang disajikan oleh media menyebabkan kerap ditemukan ketidaktepatan informasi ketika dilakukan pemeriksaan antarteks. Narasi seperti ini tidak memenuhi kriteris rasionalitas naratif dari Fisher.

Dengan mendefinisikan Soeharto sebagai tokoh baik dan buruk, media memainkan peran berita sebagai mitos. Jurnalis tidak saja menarasikan sesuatu "seperti apa adanya", tetapi menyajikannya menjadi "seperti apa maknanya". Selain itu, dengan lemahnya ketepatan naratif, memori yang disajikan tentang Soeharto lebih merupakan upaya untuk mempertahankan salah satu versi dalang dari G30S. Berita tidak lagi menyediakan fakta dan membuat sebuah relasi kausal yang argumentatif. Berita sekadar hadir untuk mempertahankan suatu kesadaran kontinum atas tatanan dunia, terlepas dari apakah hal tersebut didukung oleh informasi yang kuat atau tidak. Jurnalis cukup menjadi agen memori yang menyediakan jawaban yang "dapat diterima" atau yang "tampak masuk akal" atas suatu peristiwa.

\section{Daftar Pustaka}

Adam, Asvi Warman. 2015. "50 Tahun Studi G30S 1965.” Kompas.com. September 
30 , 2015. http://nasional.kompas.com/read/2015/0 9/30/15000011/50.Tahun.Studi.G30S.19 65 ?page $=$ all .

Affan, Heyder. 2015. "Malam Jahanam Di Hutan Jati Jeglong." BBC Indonesia. September 29, 2015. http://www.bbc.com/indonesia/berita_in donesia/2015/09/150922_indonesia_lap sus_melacakkuburanmassal.

Djarot, Eros dkk. (2006). Siapa Sebenarnya Soeharto: Fakta Dan Kesaksian Para Pelaku Sejarah G30S/PKI. Jakarta: Mediakita.

Fadillah, Ramadhian. 2015. "Saat Soeharto Marah Tak Dijadikan Pimpinan TNI AD Oleh Soekarno." Merdeka.com. September 23, 2015. https://www.merdeka.com/peristiwa/saa t-soeharto-marah-tak-dijadikanpimpinan-tni-ad-oleh-soekarno.html.

Fauzi, Gilang. 2015. "Jati Diri Masyarakat Indonesia Berubah Sejak Peristiwa 1965." CNN Indonesia. November 12, 2015.

https://www.cnnindonesia.com/nasional /20151112072200-12-91139/jati-dirimasyarakat-indonesia-berubah-sejakperistiwa-1965.

Fisher, W. R. (1987). Human Communication as Narration: Toward a Philosophy of Reason, Value, and Action. Columbia: University of South Carolina Press.

Fulton, H., Huisman, R., Murphet, J., \& Dunn, A. (2005). Narrative and Media. Cambridge: Cambridge University Press. Griffin, E. A. (2012). A First Look at Communication Theory. $8^{\text {th }} \mathrm{ed}$. New York: McGraw-Hill.

Head, Jonathan. 2015. "Berburu Dengan Waktu Mengungkap G30S." BBC Indonesia. September 30, 2015. http://www.bbc.com/indonesia/berita_in donesia/2015/09/150930_indonesia_wa ktu_g30s.

Koesoemah, Evan. 2015. "G30S 1965: Rupanya Soeharto Yang Tempatkan
Letkol Untung." Tempo.co. October 7, 2015.

https://nasional.tempo.co/read/707180/g

30s-1965-rupanya-soeharto-yang-

tempatkan-letkol-untung.

Manan, Abdul, Maria Hasugian, and Pito Agustin Rudiana. 2015. "G30S 1965: Inggris Sudah Lama Ingin Singkirkan Soekarno." Tempo.co. October 7, 2015. https://nasional.tempo.co/read/707196/g 30s-1965-inggris-sudah-lama-inginsingkirkan-soekarno.

Manuputty, Cavin R. 2015. "Membuka Tabir G30S: Hari-Hari Indonesia Di Mata CIA." Gatra.com. October 5, 2015. https://www.gatra.com/rubrik/fokusberita/167899-membuka-tabir-g30shari-hari-indonesia-di-mata-cia.

McQuail, D. (2010). Mass Communication Theory. $6^{\text {th }}$ ed. London: Sage Publications.

Mohamad, Ardyan. 2015a. "CIA Akhirnya Membuka Arsip G30S 1965, Siapa Gulingkan Soekarno?" Merdeka.com. September 20, 2015. https://www.merdeka.com/dunia/ciaakhirnya-membuka-arsip-g30s-1965siapa-gulingkan-soekarno-splitnews2.html.

Mohamad, Ardyan. 2015b. "Jaksa Sidang Rakyat 1965 Dakwa Pemerintah RI Atas 9 Pelanggaran HAM." Merdeka.com. November $11,2015$. https://www.merdeka.com/dunia/jaksasidang-rakyat-1965-dakwa-pemerintahri-atas-9-pelanggaran-ham.html.

Ningtyas, Ika. 2015a. “G30S 1965 Dan Pasukan Sipil Serba Hitam Membasmi PKI." Tempo.co. October 2, 2015. https://nasional.tempo.co/read/705938/g 30s-1965-dan-pasukan-sipil-serbahitam-membasmi-pki.

Ningtyas, Ika. 2015b. "G30S 1965, Lolos Eksekusi Mati Ditolong Tokoh Muhammadiyah." Tempo.co. October 2, 2015. https://nasional.tempo.co/read/705694/g 
30s-1965-lolos-eksekusi-mati-ditolongtokoh-muhammadiyah.

Pratama, Sandy Indra. 2015a. "Cerita Soal Soekarno, Soeharto Dan Penilaian CIA." CNN Indonesia. September 20, 2015. https://www.cnnindonesia.com/nasional /20150920032647-20-79789/cerita-soalsoekarno-soeharto-dan-penilaian-cia--3-

Pratama, Sandy Indra. 2015b. "Nama Kolonel Untung, Peristiwa 65 Dalam Dokumen CIA." CNN Indonesia. September 20, 2015.

https://www.cnnindonesia.com/nasional /20150920032224-20-79787/nama-

kolonel-untung-peristiwa-65-dalamdokumen-cia--2-/.

Pratama, Sandy Indra. 2015c. "Peristiwa 65 Dalam Rekaman Dokumen Intelijen CIA." CNN Indonesia. September 20, 2015.

https://www.cnnindonesia.com/nasional /20150920031549-20-79786/peristiwa65-dalam-rekaman-dokumen-intelijencia--1-/.

Pratomo, Yulistyo. 2015a. "Ini Pengakuan CIA Atas Tragedi 30 September Di Indonesia." Merdeka.com. September 22 , 2015. https://www.merdeka.com/peristiwa/inipengakuan-cia-atas-tragedi-30september-di-indonesia.html.

Pratomo, Sulistyo. 2015b. "Kenapa Pembunuhan Massal Usai G30S Paling Banyak Terjadi Di Bali?” Merdeka.com. October 3, 2015. https://www.merdeka.com/peristiwa/ken apa-pembunuhan-massal-usai-g30spaling-banyak-terjadi-di-bali.html.

Rastika, Icha. 2015. "Kisah Tujuh Gubernur Yang Dituduh Terlibat Gerakan PKI Dibukukan.” Kompas.com. October 1, 2015.

http://nasional.kompas.com/read/2015/1 0/01/12254261/Kisah.Tujuh.Gubernur.y ang.Dituduh.Terlibat.Gerakan.PKI.Dibu kukan?page=all.
Roosa, J. (2008). Dalih Pembunuhan Massal: Gerakan 30 September dan Kudeta Suharto. Jakarta: Institut Sejarah Nasional Indonesia dan Hasta Mitra.

Santosa, Iwan. 2015. "Peristiwa 30 September Di Mata Media Asing." Kompas.com. September 2015. http://nasional.kompas.com/read/2015/0 9/30/16000021/Peristiwa.30.September. di.Mata.Media.Asing?page=all.

Schudson, M. (2005). "News as Stories." In E. W. Rothenbuhler \& M. Coman (Eds.), Media Anthropology (pp. 121-128). London: Sage Publication.

Segal, R. A. (2004). Myth: A Very Short Introduction. Oxford: Oxford University Press.

Sulistiyo, Bambang, and Hayati Nupus. 2015. "Membuka Tabir: China Dalam Pusaran G30S.” Gatra.com. October 5, 2015. https://www.gatra.com/rubrik/fokusberita/167915-china-dalam-pusarang30s.

Sulistyo, H. (2011). Palu Arit Di Ladang Tebu: Sejarah Pembantaian Massal Yang Terlupakan (Jombang-Kediri 19651966). Jakarta: Pensil-324.

Sumsky, Victor. 2015. "Membuka Tabir G30S Dari Dokumen KGB." Gatra.com. October 5, 2015. https://www.gatra.com/rubrik/fokusberita/167884-membuka-tabir-g30sdari-dokumen-kgb.

Tempo. 2015a. "Eksklusif G30S 1965: Lelaki Lima Alias Di Operasi Penculikan." Tempo.co. October 1, 2015. https://nasional.tempo.co/read/705414/e ksklusif-g30s-1965-lelaki-lima-alias-dioperasi-penculikan.

Tempo. 2015b. "G30S, Omar Dani: Harto Tak Mau Ke Bung Karno, Itu Tak Aneh.” Tempo.co. October 1, 2015. https://nasional.tempo.co/read/705593/g 30s-omar-dani-harto-tak-mau-ke-bungkarno-itu-tak-aneh. 
Tempo. 2015c. "G30S, Omar Dani: Pesta Di Lubang Buaya Itu Isapan Jempol." Tempo.co. October 1, 2015. https://nasional.tempo.co/read/705599/g 30s-omar-dani-pesta-di-lubang-buayaitu-isapan-jempol.

Tempo. 2015d. "Omar Dani: CIA Terlibat G30S 1965 Dan Soeharto Yang Dipakai.” Tempo.co. October 1, 2015. https://nasional.tempo.co/read/705258/o mar-dani-cia-terlibat-g30s-1965-dansoeharto-yang-dipakai.

Tempo. 2015e. "G30S 1965: Ini Penyebab Di Jawa Barat Tak Ada Pembantaian." Tempo.co. October 4, 2015. https://pemilu.tempo.co/read/news/2015 /10/04/078706213/G30S-1965-IniPenyebab-di-Jawa-Barat-Tak-AdaPembantaian/0.

Tempo. 2015f. "G30S: Kisah Diplomat AS Yang Bikin Daftar Nama Target DiDor!" Tempo.co. October 5, 2015. https://nasional.tempo.co/read/706409/g 30skisah-diplomat-as-yang-bikin-daftarnama-target-di-dor.

Tempo. 2015g. "G30S 1965: Misteri Letkol Untung, Masih Hidupkah Dia?" Tempo.co. October 7, 2015. https://nasional.tempo.co/read/707154/g 30s-1965-misteri-letkol-untung-masihhidupkah-dia.

Tempo. 2015h. "G30S 1965: Terungkap, Kedekatan Soeharto Dan Letkol Untung." Tempo.co. October 7, 2015. https://nasional.tempo.co/read/707142/g 30s-1965-terungkap-kedekatansoeharto-dan-letkol-untung.

Wasono, Hari Tri. 2015. "Kisah Apel Akbar 5 Oktober 1965 Dan Pengganyang PKI." Tempo.co. October 4, 2015. https://pemilu.tempo.co/read/news/2015 /10/04/078706335/Kisah-Apel-Akbar-5Oktober-1965-dan-Pengganyang-PKI/0. 